\title{
BIBLIOGRAFIJA RADOVA PROF. DR. SC. MILANE ČERNELIĆ OD 1977. DO 2019. GODINE
}

Priredila Lorena Martinić

DOI: 10.17234/SEC.31.11 



\section{NAPOMENA PRIREĐIVAČA}

U povodu odlaska u mirovinu dr. sc. Milane Černelić, redovite profesorice u trajnom zvanju Odsjeka za etnologiju i kulturnu antropologiju Filozofskog fakulteta Sveučilišta u Zagrebu, te na zamolbu Uredništva časopisa Studia ethnologica Croatica priređena je bibliografija profesoričinih radova. Cilj je bibliografije prikazati profesoričin znanstveni i stručni rad u razdoblju od završetka njezina studija sve do tekuće godine.

Pri izradi bibliografije korištena je Bibliografija Filozofskog fakulteta, ${ }^{1}$ Repozitorij Filozofskog fakulteta u Zagrebu, ${ }^{2}$ Hrčak - portal hrvatskih znanstvenih i stručnih časopisa, ${ }^{3}$ Hrvatska znanstvena bibliografija - CROSBI (staro ${ }^{4}$ i novo ${ }^{5}$ sučelje), Agregator hrvatskih repozitorija i arhiva, ${ }^{6}$ baza doktorskih disertacija i magistarskih radova ProQuest, ${ }^{7}$ bibliografska i citatna baza Scopus, ${ }^{8}$ zbirka digitalizirane građe Australske nacionalne knjižnice TROVE, ${ }^{9}$ katalog Knjižnice Filozofskog fakulteta u Zagrebu, ${ }^{10}$ katalog Knjižnica grada Zagreba, ${ }^{11}$ katalog Nacionalne i sveučilišne knjižnice u Zagrebu, ${ }^{12}$ katalog Knjižnice Instituta za etnologiju i folkloristiku ${ }^{13}$ te ranije objavljene bibliografije radova članova Odsjeka autorica Marijane Belaj, Inje Cahun i Ivane Majer, kao i popis radova koji je sastavila profesorica Černelić.

Sukladno želji profesorice Černelić, kategorizacija i redanje radova inspirirano je "Popisom radova Vitomira Belaja" Nedjeljke Paro. Za razliku od spomenutog popisa radova, u ovoj bibliografiji nije izostavljen podatak o autoru zbog mnogobrojnih suradnji. U bibliografiju su uključeni kvalifikacijski radovi (magistarski i doktorski rad), autorske i uredničke knjige, znanstveni i pregledni radovi, stručni radovi i sažeci sa skupova te ostale vrste radova (sažeci, uvodi, pogovori, prijevodi, bibliografije, feljtoni, recenzije, prikazi, natuknice u leksikonu), kao i popis radova studenata koje je profesorica mentorirala.

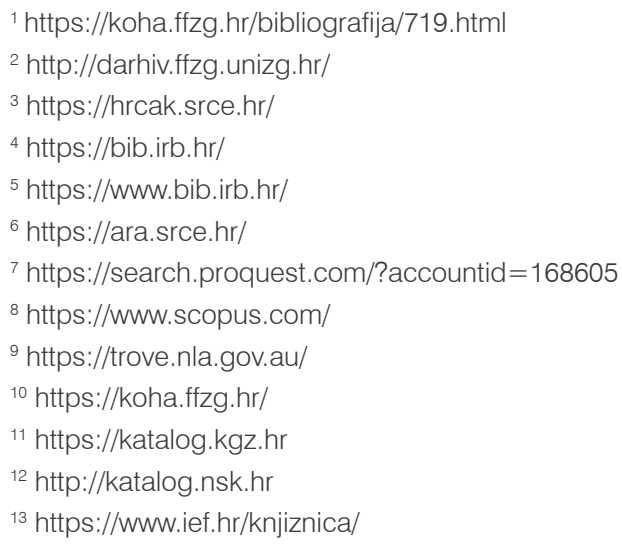


U dogovoru s profesoricom Černelić, odabrano je kronološko redanje radova, od starijih prema novijim, te su popisani abecedno prema prezimenu prvog autora. U slučaju časopisa Studia ethnologica Croatica i Etnološka tribina u kojima se u ponekim starijim brojevima ne poklapaju godište i datum dovršetka tiska, odabran je datum prihvaćanja rada kao kriterij za kronološko redanje bibliografskih jedinica.

Profesorica Černelić prisustvovala je na šezdesetak domaćih i međunarodnih skupova, autorica je četiriju autorskih publikacija te je sudjelovala u izradi devet publikacija kao glavna urednica ili dio uredništva. U bibliografiju su uvršteni isključivo objavljeni radovi među kojima je 71 znanstveni članak, 26 stručnih, 5 enciklopedijskih natuknica te 27 ostalih vrsta radova. Tijekom svoje dugogodišnje profesorske karijere mentorirala je tri doktorske disertacije te četrdesetak diplomskih radova.

Način citiranja korišten pri izradi ove bibliografije u skladu je s preporukama u časopisu Studia ethnologica Croatica uz minimalne intervencije koje su elaborirane u daljnjem tekstu. Osnovnu strukturu bibliografske jedinice čine prezime i ime autora odnosno urednika, godina, naslov rada, naslov izvornika (knjige, zbornika, časopisa u kojem je rad objavljen), mjesto izdanja, podatak o nakladniku te, ako je riječ o članku ili poglavlju knjige, navedene su početna i završna stranica rada. Publikacijama koje su dostupne u otvorenom pristupu pridružena je i poveznica na mrežnu inačicu. Način navođenja usporednih naslova preuzet je iz najrecentnije odsječke bibliografije, one iz 2018. godine, koju je sastavila Inja Cahun: originalni naslov i prijevod rada odvojeni su kosom crtom (/), a ako je naslov rada preveden uz sažetak, koristi se znak jednakosti $(=)$, i u oba je slučaja u uglatim zagradama opaska radi li se o prijevodu ili sažetku.

\section{LITERATURA}

BELAJ, Marijana. 2006. "Izdavaštvo Odsjeka za etnologiju i kulturnu antropologiju".

Studia ethnologica Croatica, vol. 18:71-94. https://hrcak.srce.hr/17522

CAHUN, Inja. 2018. "Bibliografija radova objavljenih u časopisu 'Studia ethnologica Croatica' od 2006. do 2017. godine". Studia ethnologica Croatica, vol. 30:345-385. DOI: https://doi.org/10.17234/SEC.30.12

MAJER, Ivana. 2017. "Bibliografija Odsjeka za etnologiju i kulturnu antropologiju Filozofskog fakulteta Sveučilišta u Zagrebu (2006. - 2016.)". Studia ethnologica Croatica. vol. 29:411-496. https://hrcak.srce.hr/191709

PARO, Nedjeljka. 2009. "Popis radova Vitomira Belaja". U Etnolog Vitomir Belaj: zbornik radova povodom 70. rođendana Vitomira Belaja, ur. Tihana Petrović Leš. Zagreb: Filozofski fakultet Sveučilišta u Zagrebu, Odsjek za etnologiju i kulturnu antropologiju, FF-press, 37-73. 


\section{KVALIFIKACIJSKI RADOVI}

\section{Magistarski rad}

ČERNELIĆ, Milana. 1988. Tradicije svatovskih časti, njihovi nazivi i uloge, s obzirom na pojavu i uloge staćela. Zagreb: M. Černelić.

\section{Doktorska disertacija}

ČERNELIĆ, Milana. 1997. Odabrane pojave iz svadbenih običaja bunjevačkih Hrvata kao izvor za proučavanje njihove etnogeneze.

Zagreb: M. Černelić.

\section{AUTORSKE KNJIGE}

1991

2006

2016

2018
ČERNELIĆ, Milana. 1991. Uloge i nazivi odabranih svatova u Bunjevaca.

Zagreb: Etnološki zavod Filozofskog fakulteta Sveučilišta u Zagrebu.

ČERNELIĆ, Milana. 2006. Bunjevačke studije. Zagreb: Filozofski fakultet Sveučilišta u Zagrebu, Odsjek za etnologiju i kulturnu antropologiju, FF-press.

ČERNELIĆ, Milana. 2016. Bunjevci - ishodišta, sudbine, identiteti. Zagreb: Filozofski fakultet Sveučilišta u Zagrebu, Odsjek za etnologiju i kulturnu antropologiju, FF-press - Subotica: Zavod za kulturu vojvođanskih Hrvata. https://openbooks.ffzg.unizg.hr/index.php/FFpress/catalog/ book/14 (pristup 5. 7. 2019.)

ČERNELIĆ, Milana. 2018. Bunjevci: migrations, traditional heritage, identities. Beau Bassin: Scholars' press. http://darhiv.ffzg.unizg.hr/id/eprint/9575/ (pristup 5. 7. 2019.)

\section{UREDNIČKE KNJIGE} obiteljske zadruge. Sv. 2: Izvorna građa za 19. i 20. stoljeće. Zagreb: Otvoreno sveučilište. 
ČERNELIĆ, Milana, Nevenka FABIAN, Tihana PETROVIĆ, Marija ŠERCER, Naco ZELIĆ i Marija ZAIĆ KUBATOVIĆ, ur. 1998. Iz baštine bačkih Hrvata Bunjevaca: Etnografski muzej, 17. veljače - 17. ožujka 1998. Zagreb: Etnografski muzej.

ČERNELIĆ, Milana, Marijeta RAJKOVIĆ i Tihana RUBIĆ, ur. 2009. Živjeti na Krivom Putu. Sv. 3: Život mladih, pripreme za brak i sklapanje braka. Zagreb: Filozofski fakultet Sveučilišta u Zagrebu, Odsjek za etnologiju i kulturnu antropologiju, FF-press - Senj: Gradski muzej.

Živjeti na Krivom Putu. Sv. 2: Etnološka monografija o primorskim Bunjevcima. Zagreb: Filozofski fakultet Sveučilišta u Zagrebu, Odsjek za etnologiju i kulturnu antropologiju, FF-press - Senj: Gradski muzej.

Živjeti na Krivom Putu. Sv. 1: Etnološko-povijesna monografija o primorskim Bunjevcima. Zagreb: Filozofski fakultet Sveučilišta u Zagrebu, Odsjek za etnologiju i kulturnu antropologiju, FF-press - Senj: Gradski muzej.

ČERNELIĆ, Milana, Marijeta RAJKOVIĆ i Tihana RUBIĆ, ur. 2009. antropologilu, FF-press-Senj: Gradski muzej. \\ 2010}

ČERNELIĆ, Milana i Marijeta RAJKOVIĆ IVETA, ur. 2010. Zapisi iz Gornjih Ravnih kotara: etnološki, povijesni i muzeološki prilozi o Islamu Latinskom, Islamu Grčkom, Kašiću i Podgradini. Zagreb: Filozofski fakultet Sveučilišta u Zagrebu, Odsjek za etnologiju i kulturnu antropologiju, Centar za komparativnohistorijske i interkulturne studije, FF-press. http://kula-jankovica.unizg.hr/files/file/DS-02-Ravni-kotari.pdf (pristup 5. 7. 2019.)

2014 ČERNELIĆ, Milana, gl. ur. 2014. Tradicijska baština i etnokulturni identitet podunavskih Hrvata Bunjevaca. Zagreb: Filozofski fakultet Sveučilišta u Zagrebu, Odsjek za etnologiju i kulturnu antropologiju, FF-press - Subotica: Zavod za kulturu vojvođanskih Hrvata.

ČERNELIĆ, Milana, Jadranka GRBIĆ JAKOPOVIĆ, Marijeta RAJKOVIĆ IVETA, Tihana RUBIĆ, Matija DRONJIĆ i Mihovil GOTAL, ur. 2014. Bunjevci u vremenskom i prostornom kontekstu. Zagreb: Filozofski fakultet Sveučilišta u Zagrebu, Odsjek za etnologiju i kulturnu antropologiju, FF-press - Subotica: Zavod za kulturu vojvođanskih Hrvata. 

Hrvata Šokaca. Zagreb: Filozofski fakultet Sveučilišta u Zagrebu, Odsjek za etnologiju i kulturnu antropologiju, FF-Press - Subotica: Zavod za kulturu vojvođanskih Hrvata.

\section{ZNANSTVENI I PREGLEDNI RADOVI}

1984

1985

1986

1988

1989

1990

ČERNELIĆ, Milana. 1984. "Egy zombori mézeskalácsos családrol". Folklór és traditió, vol. 1:222-236.

ČERNELIĆ, Milana. 1985. "Socijalno-ekonomski aspekti kontinuiteta i promjena u običajima pri sklapanju braka u jednom madžarskom selu u Bačkoj". Zbornik radova XXXII kongresa Saveza udruženja folklorista Jugoslavije održanog u Somboru 1985. godine, vol. 1:41-46.

ČERNELIĆ, Milana, Libuše KAŠPAR, Smiljana PETR-MARČEC i Nives RITIG-BELJAK. 1986. "Značajke tradicijske ishrane težaka u Lipovljanima" = "Characteristics of traditional nutrition of farm hands in Lipovljani" [Summary] = "Tradični jidla nádeniku v Lipovlanech" [Resumé]. U Lipovljanski susreti 89: istraživanje, prezentacija i zaštita kulture narodnosti, ur. Nives Ritig-Beljak, Blaženka Špoljarić i Ante Mihaljević. Lipovljani: Savjet i Organizacijski odbor "Lipovljanskih susreta", Zavod za istraživanje folklora Zagreb, 97-113.

ČERNELIĆ, Milana. 1988. "Običaj plesa s nevjestom u svadbenim običajima Bunjevaca" = "A menyasszonytánc a bunyevácok lakodalmi szokásaiban" [Absztrakt]. Folklór és traditió, vol. 5:114-130.

ČERNELIĆ, Milana. 1989. "Svatovska grana kod južnih Slavena" = "South Slavic wedding tree" [Summary]. U Zbornik radova: XXXVI Kongresa Saveza udruženja folklorista Jugoslavije, ur. Dragoslav Antonijević.

Beograd: Udruženje folklorista Srbije, 117-120.

ČERNELIĆ, Milana. 1990. "Kravaj u svadbenim običajima južnih Slavena" = "Kravaj in the south Slav wedding customs" [Summary]. Etnološka tribina, vol. 19, no. 20:21-31. https://hrcak.srce.hr/80516 (pristup 5. 7. 2019.)

ČERNELIĆ, Milana. 1990. "O tragovima zadruge kod Bunjevaca u južnoj Mađarskoj" = "On the Traces of the Zadruga among the Bunjevci of 
South Hungary" [Summary]. Migracije i etničke teme, vol. 6, no. 3:311323. https://hrcak.srce.hr/127676 (pristup 5. 7. 2019.)

ČERNELIĆ, Milana. 1991. "Pristup pitanjima svatovske grane u južnih Slavena" = "An approach to the question of marriage branch among south Slavs" [Summary]. Etnološka tribina, vol. 21, no. 14:103-114. https://hrcak.srce.hr/80652 (pristup 5. 7. 2019.)

ČERNELIĆ, Milana. 1991. "Role of the Starješina svatova among the Bunjevci" = "Uloga starješine svatova kod Bunjevaca" [Sažetak]. Studia ethnologica Croatica, vol. 3:181-191. https://hrcak.srce.hr/75772 (pristup 5. 7. 2019.)

ČERNELIĆ, Milana. 1992. "Zadružne obitelji roda Blažević-Marinkić u nekoliko generacija (od sredine 19. stoljeća do 1946 godine)". U Seljačke obiteljske zadruge. Sv. 2: Izvorna građa za 19. i 20. stoljeće, ur. Jasna Andrić, Milana Črnelić i Tihana Petrović. Zagreb: Otvoreno sveučilište, 105-121.

ČERNELIĆ, Milana. 1993. "'Kravaj' as a gift in the wedding customs of the southern Slaves" = "'Kravaj' jako dar w obrzędowości weselnej u południowxch Słowian" [Streszczenie]. Prace etnograficzne, vol. 31:163-176.

ČERNELIĆ, Milana. 1993. "Na tragovima izvorištu osebujnoga postupka pri blagoslovu mladenaca u podunavskih Bunjevaca iz okolice Budimpešte" = "Following the characteristic procedures of blessing in wedding customs of the Dunabe Bunjevci in the surroundings of Budapest" [Summary]. Studia ethnologica Croatica, vol. 5:63-79. https://hrcak.srce.hr/75649 (pristup 5. 7. 2019.)

ČERNELIĆ, Milana. 1994. "Ethnic changes in Vojvodina in the 20th century with special reference to the position of the Croats Bunjevci". $\mathrm{U}$ Ethnocultural processes in Central Europe in the 20-th century = Etnokulturelle Prozesse in Mitteleutopa im 20. Jahrhundert. Bratislava: Univerzita Komenského, Katedra etnologie, 55-86.

ČERNELIĆ, Milana. 1994. "Nastojanja da se bačkim Bunjevcima ospori pripadnost hrvatskom narodu" = "Attempts to Deny the Bunjevci of Bačka the Rights to Belong to the Croat Nation" [Summary]. Studia ethnologica Croatica, vol. 6:85-103. https://hrcak.srce.hr/68238 (pristup 5. 7. 2019.) 
ČERNELIĆ, Milana. 1994. "Tradicije paljenja godišnjih vatri kao indikator kulturnih razlika" = "The traditions of lightning fires during the seasonal festivities as an indication of cultural differences" [Summary]. Etnološka tribina, vol. 24, no. 17:25-42. https://hrcak.srce.hr/80704 (pristup 5. 7. 2019.)

ČERNELIĆ, Milana. 1994. "A Budapest környéki, Duna menti Bunyevácok lakodalmi áldása nyomában". Ethnográphia, vol. 105, no. 2:459-476.

ČERNELIĆ, Milana. 1995. "Specific Features in the Tradition of Lighting Fires during the Seasonal Festivities as an Indicator of Ethnic Differences". U Meeting of Cultures - Conflicts of Cultures (Lectures of Vth International Conference on Ethnographic Nationality Research), Békéscsába, 7-8-9 October 1993:243-251.

ČERNELIĆ, Milana. 1996. "Änderungen in den Eheschiessungsbräuchen in einem ungarischen Dorf in der Batschka". Acta Ethnographica Hungarica, vol. 41, no. 1/4:233-259.

ČERNELIĆ, Milana. 1997. "Attempts to deny the Bunjevci of Bačka (Vojvodina) the Right to Belong to the Croat Nation". Acta Ethnographica Hungarica, vol. 42, no. 1/2:175-186.

ČERNELIĆ, Milana. 1997. "Uvod u raspravu o etnološkoj kartografiji: poticaj za istraživanje na primjeru teme o godišnjim vatrama" = "An Introduction to Discussion about Ethnological Cartography: An Incentive for the Research on the Example of Annual Bonfires" [Summary]. Studia ethnologica Croatica, vol. 9:5-15. https://hrcak.srce.hr/59845 (pristup 5. 7. 2019.)

ČERNELIĆ, Milana. 1998. "Kroz godinu dana srijemskih običaja vukovarskog kraja" = "Annual customs of Srijem in the Vukovar region" [Summary]. Etnološka tribina, vol. 28, no. 21:129-140. https://hrcak.srce.hr/80816 (pristup 5. 7. 2019.) 
ČERNELIĆ, Milana. 1999. "Osobitosti pojedinih običaja pri sklapanju braka u Lici" = "Characteristics of some wedding customs in Lika" [Summary]. Etnološka tribina: godišnjak Hrvatskog etnološkog društva, vol. 29, no. 22:47-52. https://hrcak.srce.hr/80874 (pristup 5. 7 .2019.)

ČERNELIĆ, Milana. 1999. "Tragovi bunjevačkih elemenata u svadbenim običajima Like i Primorja: svatovska čast kuma" = "Traces of the elements of Bunjevci-Croats in wedding customs of Lika and Primorje: wedding honour of the best man" [Summary]. Etnološka tribina, vol. 29, no. 22:37-46. https://hrcak.srce.hr/80873 (pristup 5. 7. 2019.)

ČERNELIĆ, Milana. 1999. "Zadruga Rukavina-Jauci iz Smiljanskog Polja kod Gospića" = "Familiengenossenschaft Rukavina-Jauci aus Smiljansko Polje bei Gospić" [Zusammenfassung] = "The Rukavina-Jausci cooperative from Smiljan Field near Gospić" [Summary]. Senjski zbornik: prilozi za geografiju, etnologiju, gospodarstvo, povijest $i$ kulturu, vol. 26:297-312. https://hrcak.srce.hr/42620 (pristup 5. 7. 2019.)

ČERNELIĆ, Milana. 2000. "Kolač/kruh u obredu prstenovanja i blagoslova mladenaca u Bunjevaca iz okolice Budimpešte". Etnografija Hrvata u Mađarskoj, vol. 7:81-95.

"Zwei Familiengenosseschaften auf dem Gebiet von Krivi Put" [Zusammenfassung] = "The two cooperative families in the region of Krivi Put" [Summary]. Senjski zbornik: prilozi za geografiju, etnologiju, gospodarstvo, povijest i kulturu, vol. 27:199-216. https://hrcak.srce.hr/ 29231 (pristup 5. 7. 2019.)

ČERNELIĆ, Milana. 2001. "Über das Recht, ein Kroate zu sein: zu den Verssuchen, den Bunjevci aus Bačka die Zugehörigkeit zum kroatischen Volk abzusprechen". U Kroatische Volkskunde/Ethnologie in den Neunzigern, ur. Jasna Čapo Žmegač, Reinhard Johler, Sanja Kalapoš i Herbert Nikitsch. Wien: Verlag des Instituts für Europäische Ethnologie, 207-234.

ČERNELIĆ. Milana. 2002. "Povezanost života na salašu i u gradu bačkih Bunjevaca" = "Connections between living on the 'salaš' and in the town among the Bunjevci Croats in Bačka" [Summary]. Etnološka tribina, vol. 32, no. 25:99-103. https://hrcak.srce.hr/27718 (pristup 5. 7. 2019.) 
ČERNELIĆ, Milana. 2003. "Istraživanje tradicijske baštine, identiteta i etnogeneze primorskih Bunjevaca" = "Investigation of traditional heritage, identity and ethno-genesis of coastal Bunjevci" [Summary] = "Die Untersuchung des Kulturerbes, der Identität und der Ethnogenese der küstenländichen Bunjevacer" [Zusammenfassung]. Senjski zbornik: prilozi za geografiju, etnologiju, gospodarstvo, povijest i kulturu, vol. 30:407-424. https://hrcak.srce.hr/17882 (pristup 5. 7. 2019.)

ČERNELIĆ, Milana. 2003. "Pojava 'vukova' u svadbenim običajima u okolici Novske" = "The Appearance of Vukovi in the Wedding Customs near Novska" [Summary]. Studia ethnologica Croatica, vol. 12/13:125-134. https://hrcak.srce.hr/48529 (pristup 5. 7. 2019.)

ČERNELIĆ, Milana. 2003. "Svatovska čast 'kuma' u okolici Novske u prostornom kontekstu" = "A member of the wedding party called Kum, as found around the town of Novska, in spatial context" [Summary]. Studia ethnologica Croatica, vol. 12/13:135-143. https://hrcak.srce.hr/48530 (pristup 5. 7. 2019.)

ČERNELIĆ, Milana. 2003. "Watercrossing of the Wedding Procession" = "Prijelaz preko vode prije ulaska svadbene povorke u kuću" [Sažetak]. Studia ethnologica Croatica, vol. 14/15:5-21. https://hrcak.srce.hr/47755 (pristup 5. 7. 2019.)

2004 ČERNELIĆ, Milana. 2004. "The local community of the ethnic Bunjevci in Croatia: developing cultural identity". U Times, places, passages. Ethnological approaches in the New Millennium, gl. ur. Attila PaládiKovács. Budapest: Akadémiai Kaidó, 119-133.

2006 ČERNELIĆ, Milana. 2006. "Pristupi istraživanju bunjevačkih identiteta" = "Approaches to the research of the identity of the ethnic group of Bunjevci" [Summary]. Studia ethnologica Croatica, vol. 17:25-49. https://hrcak.srce.hr/4945 (pristup 5. 7. 2019.)

ČERNELIĆ, Milana. 2006. "Specifičan način darivanja nevjeste u bunjevačkim svadbenim običajima". Etnološka tribina, vol. 36, no. 29:113-131. http://hrcak.srce.hr/27541 (pristup 5. 7. 2019.) tradicijske baštine na području Krivoga Puta u senjskome zaleđu" = "Possibilities of Revitalization of Traditional Heritage in the Region of 
Krivi Put near the Town of Senj" [Summary]. Studia ethnologica Croatica, vol. 19:245-268. https://hrcak.srce.hr/22136 (pristup 5. 7. 2019.)

ČERNELIĆ, Milana. 2007. "Bunjevački elementi u svadbenim običajima". U Dalmatinska zagora - nepoznata zemlja: Galerija Klovićevi dvori, Zagreb, 4. rujna - 21. listopada 2007., ur. Joško Belamarić i Marko Grčić. Zagreb: Ministarstvo kulture Republike Hrvatske, Galerija Klovićevi dvori, 583-588.

ČERNELIĆ, Milana. 2007. "Kroz godinu dana srijemskih običaja vukovarskog kraja”. U Šokadija i Šokci, 2. Život i običaji: o hrvatskom grbu i identitetu o pokladnim, uskrsnim, božićnim, svadbenim, pogrebnim i drugim običajima kroz godinu, o pučkim i dječjim igrama, o radovima u polju, blagu i živadi, o vinogradima, stanarima, ribolovu, o starim zanatima, narodnom vezu i rukotvorstvu, darovanju i milošću, nakitu i češljanju, o narodnim nošnjama, pjesmama u kolu, ur. Zdenka Lechner i Martin Grgurovac. Vinkovci: Privlačica - Ilača: Tiskara Pauk, 191-197.

ČERNELIĆ, Milana. 2007. "Obredne vatre bačkih Šokaca u hrvatskom i europskom prostornom kontekstu". U Šokadija i Šokci, 2. Život i običaji: o hrvatskom grbu i identitetu o pokladnim, uskrsnim, božićnim, svadbenim, pogrebnim i drugim običajima kroz godinu, o pučkim i dječjim igrama, o radovima u polju, blagu i živadi, o vinogradima, stanarima, ribolovu, o starim zanatima, narodnom vezu i rukotvorstvu, darovanju i milošću, nakitu i češljanju, o narodnim nošnjama, pjesmama u kolu, ur. Zdenka Lechner i Martin Grgurovac. Vinkovci: Privlačica Ilača: Tiskara Pauk, 508-511.

ČERNELIĆ, Milana. 2007. "Prilog poznavanju kulturnopovijesne metode u hrvatskoj etnologiji i raspravi o njoj" = "Contribution to Understanding and Discussion of Cultural-Historical Method in Croatian Ethnology" [Summary]. Studia ethnologica Croatica, vol. 19:5-16. https://hrcak.srce.hr/22110 (pristup 5. 7. 2019.)

ČERNELIĆ, Milana. 2007. "Common Elements of the Bridal Gift-Giving in the Wedding Customs of the Bunjevci, the Vlach and other Balkan Peoples". македонски фолклор = Macedonian folklore, vol. 64:123-142. Pečuški horizont = Pécsi horizont, vol. 2:209-217. 
ČERNELIĆ, Milana. 2008. "Specifičan način darivanja nevjeste u bunjevačkim svadbenim običajima". Etnografija Hrvata u Mađarskoj, vol. 13:39-56.

ČERNELIĆ, Milana i Marijeta RAJKOVIĆ. 2009. "Mogućnosti korištenja elemenata tradicijske kulture u revitalizaciji krivoputskog područja". U Živjeti na Krivom Putu. Sv. 2: Etnološka monografija o primorskim Bunjevcima, ur. Milana Černelić, Marijeta Rajković i Tihana Rubić. Zagreb: Filozofski fakultet Sveučilišta u Zagrebu, Odsjek za etnologiju i kulturnu antropologiju, FF-press - Senj: Gradski muzej, 313-324.

ČERNELIĆ, Milana i Tihana RUBIĆ. 2009. "Običaji životnoga ciklusa". U Slavonija, Baranja i Srijem: vrela europske civilizacije. Galerija Klovićevi dvori, Zagreb, 27. travnja - 2. kolovoza 2009. Drugi svezak, ur. Vesna Kusin i Branka Šulc. Zagreb: Ministarstvo kulture Republike Hrvatske, Galerija Klovićevi dvori, 148-159.

ČERNELIĆ, Milana. 2009. "Običajno-pravni i imovinski aspekti života u obiteljskim zadrugama Like" = "Common-law and property aspects of life in family cooperatives of Lika" [Summary]. Senjski zbornik: prilozi za geografiju, etnologiju, gospodarstvo, povijest $i$ kulturu, vol. 36:301322. http://hrcak.srce.hr/57617 (pristup 5. 7. 2019.)

ČERNELIĆ, Milana. 2009. "Pristupi istraživanju bunjevačkih identiteta”. Godišnjak za znanstvena istraživanja Zavoda za kulturu vojvođanskih Hrvata, vol. 1:159-183. http://www.zkvh.org.rs/index.php/dokumenti/send/132009/950-cernelic2009r (pristup 5. 7. 2019.)

ČERNELIĆ, Milana. 2009. "Slijedom bunjevačkih elemenata u svadbenim običajima Like" = "Following the Bunjevci Elements in the Wedding Customs of Lika" [Summary]. U Identitet Like: korijeni i razvitak, knj. 2, ur. Željko Holjevac. Zagreb: Institut društvenih znanosti Ivo Pilar - Gospić: Institut društvenih znanosti Ivo Pilar, Područni centar, 213-228. https://www.pilar.hr/wp-content/images/stories/dokumenti/ lika/lika_2_mail_r_213.pdf (pristup 5. 7. 2019.)

ČERNELIĆ, Milana. 2009. "Život zadružne obitelji: dvije studije slučaja". U Živjeti na Krivom Putu. Sv. 2: Etnološka monografija o primorskim Bunjevcima, ur. Milana Černelić, Marijeta Rajković i Tihana Rubić. Zagreb: Filozofski fakultet Sveučilišta u Zagrebu, Odsjek za etnologiju i kulturnu antropologiju, FF-press - Senj: Gradski muzej, 77-89. 
ČERNELIĆ, Milana i Biserka JARAMAZOVIĆ. 2010. "Tradicijska obilježja zaručnog darivanja kao simbol identiteta bunjevačkih Hrvata" = "Traditional characteristics of gifting at engagement as a symbol of identity among the Croats of Bačka" [Summary]. U Identitet bačkih Hrvata: zbornik radova međunarodnog znanstvenog skupa (Zagreb, 27. i 28. studenoga 2008.), ur. Robert Skenderović. Zagreb: Hrvatski institut za povijest - Subotica: Hrvatsko akademsko društvo, 215-240.

ČERNELIĆ, Milana i Marijeta RAJJKOVIĆ IVETA. 2010. "Ogled o primorskim Bunjevcima: povijesna perspektiva i identifikacijski procesi" = "Review on Coastal Bunjevci: Historical Perspective and the Processes of Identification" [Summary]. Studia ethnologica Croatica, vol. 22:283-316. https://hrcak.srce.hr/62255 (pristup 5. 7. 2019.)

ČERNELIĆ, Milana i Marijeta RAJKOVIĆ IVETA. 2010. "Uvod. Zapisi iz gornjih Ravnih kotara. Etnološki, povijesni i muzeološki prilozi o Islamu Latinskom, Islamu Grčkom, Kašiću i Podgradini”. U Zapisi iz gornjih Ravnih kotara: etnološki, povijesni i muzeološki prilozi o Islamu Latinskom, Islamu Grčkom, Kašiću i Podgradini, ur. Milana Černelić i Marijeta Rajković Iveta. Zagreb: Filozofski fakultet Sveučilišta u Zagrebu, Odsjek za etnologiju i kulturnu antropologiju, Centar za komparativnohistorijske i interkulturne studije, 7-25. http://kula-jankovica.unizg.hr/files/file/DS-02-Ravni-kotari.pdf (pristup 5. 7. 2019.)

ČERNELIĆ, Milana. 2010. "Velika familija Dulić na Đurđinu" = "Large family Dulic in Djurdjin" [Summary]. Godišnjak za znanstvena istraživanja Zavoda za kulturu vojvođanskih Hrvata, vol. 2:107-139. http://www.zkvh.org.rs/index.php/dokumenti/send/14-2010/924cernelic2010r (pristup 5. 7. 2019.)

GALIĆ, Ivan i Milana ČERNELIĆ. 2010. "Pregled godišnjih običaja". U Zapisi iz Gornjih Ravnih kotara: etnološki, povijesni i muzeološki prilozi o Islamu Latinskom, Islamu Grčkom, Kašiću i Podgradini, ur. Milana Černelić i Marijeta Rajković Iveta. Zagreb: Filozofski fakultet Sveučilišta u Zagrebu, Odsjek za etnologiju i kulturnu antropologiju, Centar za komparativnohistorijske i interkulturne studije, FF-press, 255-300. http://kula-jankovica.unizg.hr/files/file/DS-02-Ravni-kotari.pdf (pristup 5. 7. 2019.)

2011 ČERNELIĆ, Milana. 2011. "Velika kuća Ivana Opštinara na salašima Matarići kod 
Sombora - Usporedni osvrt na zadruge na salašima na Bezdanskom putu" = "Great house of Ivan Opštinar on Matarić granges near Sombor - Comperative review of the cooperatives on granges on Bezdan Road" [Summary]. Godišnjak za znanstvena istraživanja Zavoda za kulturu vojvođanskih Hrvata, vol. 3:187-204.

http://www.zkvh.org.rs/index.php/dokumenti/send/15-2011/939cernelic2011r (pristup 5. 7. 2019.)

ČERNELIĆ, Milana. 2012. "The Impact of Migration on the Cultural Heritage and Identity. The Example of the Croat (Sub)Ethnic Group Bunjevci".

U Migration and identity: historical, cultural and linguistic dimensions of mobility in the Balkans, ur. Petko Hristov. Sofia: Paradigma, 163-179.

\section{trajanja 'Dužijance' - proslava završetka žetve kao kulturna praksa i iskazivanje identiteta" = "A hundred and two years of 'Dužijanca' - the manifestation in honour of the end of the harvest as a cultural practice and an expression of identity" [Summary]. U FEB 2012: zbornik radova. Međunarodni znanstveni interdisciplinarni simpozij Hrvatska folklorna i etnografska baština u svjetlu dubrovačke, svjetske i turističke sadašnjosti, Dubrovnik 11.-13. prosinca 2012., ur. Mira Muhoberac. Dubrovnik: Folklorni ansambl Linđo, 500-515.}

ČERNELIĆ, Milana. 2013. "Folklorizacija identiteta: obnovljeni bunjevački običaj ophoda kraljica u Mađarskoj". U XI. međunarodni kroatistički znanstveni skup: zbornik radova, ur. Stjepan Blažetin. Pečuh: Znanstveni zavod Hrvata u Mađarskoj, 9-26. obiteljskog života u drugoj polovini 20. stoljeća u Kruševu". U Kula Jankovića: spomenik kulture - pokretač održivog razvoja Ravnih kotara: baština, interkulturalizam i revitalizacija: zbornik radova, ur. Drago Roksandić, Marijeta Rajković Iveta i Tihana Rubić. Zagreb: FilozofskifakultetSveučilištauZagrebu, Centarzakomparativnohistorijske i interkulturne studije, Plejada, 21-34. http://kula-jankovica.unizg.hr/ files/file/DS-09-Kula-Jankovica.pdf (pristup 5. 7. 2019.)

BIRT KATIĆ, Danijela i Milana ČERNELIĆ. 2014. "Oblici zadružnog života u drugoj polovici 20. stoljeća u Kruševu (Bukovica)" = "Forms of cooperative life in the second half of the 20th century in Kruševo (Bukovica)" [Summary]. U Bunjevci u vremenskom i prostornom 
kontekstu, ur. Milana Černelić, Jadranka Grbić Jakopović, Marijeta Rajković Iveta, Tihana Rubić, Matija Dronjić i Mihovil Gotal. Zagreb: FF-press, 327-344.

ČERNELIĆ, Milana i Biserka JARAMAZOVIĆ ĆURKOVIĆ. 2014. "Tradicijska obilježja zaručnog darivanja kao simbol identiteta bunjevačkih Hrvata". U GRBIĆ JAKOPOVIĆ, Jadranka. 2014. Multipliciranje zavičaja i domovina. Hrvatska dijaspora: kronologija, destinacije i identitet. Zagreb: Filozofski fakultet u Zagrebu, Odsjek za etnologiju i kulturnu antropologiju, FF-press, 155-169.

ČERNELIĆ, Milana i Jadranka GRBIĆ JAKOPOVIĆ. 2014. "Dužijanca - etnološka percepcija i interpretacija" = "Duzijanca (harvest-day celebration) ethnological perception and interpretation" [Summary]. Godišnjak za znanstvena istraživanja Zavoda za kulturu vojvođanskih Hrvata, vol. 6:217-227. http://www.zkvh.org.rs/attachments/article/2829/ 06\%2Cernelic2014.pdf (pristup 5. 7. 2019.)

ČERNELIĆ, Milana i Bojana POLJAKOVIĆ. 2014. "Uskrsni običaji". U Tradicijska baština i etnokulturni identitet podunavskih Hrvata Bunjevaca, gl. ur. Milana Černelić. Zagreb: Filozofski fakultet Sveučilišta u Zagrebu, Odsjek za etnologiju i kulturnu antropologiju, FF-press - Subotica: Zavod za kulturu vojvođanskih Hrvata, 135-190.

ČERNELIĆ, Milana i Tamara ŠTRICKI SEG. 2014. "Ophodi kraljica". U Tradicijska baština i etnokulturni identitet podunavskih Hrvata Bunjevaca, gl. ur. Milana Černelić. Zagreb: Filozofski fakultet Sveučilišta u Zagrebu, Odsjek za etnologiju i kulturnu antropologiju, FF-press - Subotica: Zavod za kulturu vojvođanskih Hrvata, 191-238.

ČERNELIĆ, Milana. 2014. "Sveti Ivan Cvitnjak". U Tradicijska baština i etnokulturni identitet podunavskih Hrvata Bunjevaca, gl. ur. Milana Černelić. Zagreb: Filozofski fakultet Sveučilišta u Zagrebu, Odsjek za etnologiju i kulturnu antropologiju, FF-press - Subotica: Zavod za kulturu vojvođanskih Hrvata, 265-273. zadruga (extended family) of the Croatian subethnic group of Bunjevci" Acta ethnographica Hungarica, vol. 61, no. 2:443-468. http://www.akad emiai.com/doi/abs/10.1556/022.2016.61.2.12 (pristup 5. 7. 2019.) 
ČERNELIĆ, Milana. 2016. "The Role of Ritual Traditional Clothing among Bunjevci Croats in Serbia in the Revitalisation of Annual Customs and Rituals". Folklore: Electronic Journal of Folklore, vol. 66:59-78.

http://www.folklore.ee/folklore/vol66/cernelic.pdf (pristup 5. 7. 2019.)

ČERNELIĆ, Milana. 2018. "O mogućim bunjevačkim ishodištima". Etnografija Hrvata u Mađarskoj, vol. 16:29-49.

MAROEVIĆ, Lucija, Karlo SRDOČ i Milana ČERNELIĆ. 2018. "Prakse tradicijske glazbe". U Tradicijska baština, identitet i migracije bačkih Hrvata Šokaca, gl. ur. Milana Černelić. Zagreb: Filozofski fakultet Sveučilišta u Zagrebu, Odsjek za etnologiju i kulturnu antropologiju, FF-Press Subotica: Zavod za kulturu vojvođanskih Hrvata, 441-484.

PERIŠKIĆ PEJAK, Sonja i Milana ČERNELIĆ. 2018. "Posmrtni običaji kroz 20. stoljeće". U Tradicijska baština, identitet i migracije bačkih Hrvata Šokaca, gl. ur. Milana Černelić. Zagreb: Filozofski fakultet Sveučilišta u Zagrebu, Odsjek za etnologiju i kulturnu antropologiju, FF-Press Subotica: Zavod za kulturu vojvođanskih Hrvata, 503-572.

\section{STRUČNI RADOVI I SAŽECI SA SKUPOVA}

ČERNELIĆ, Milana, Vesna LOVRIĆ, Blagoje JANKOVIĆ, Kornelija OLIĆ, Željko ILIĆ, Janko ŠMIGOC, Saša DIMIĆ, Milan KARADŽIĆ, Dragoljub DIVLJANOVIĆ i Svetislav POP-CENIĆ. 1980. "Etnomedicina i etnoveterina Poljanice i okolice Gnjilana" = "Ethnomedicine and ethnoveterine of Poljanice and the vicintiy of Gnjilane" [Contents]. Narodna zdravstvena kultura u Srbiji, vol. 4:133-239. za godinu 1991., ur. Željko Obad. Zagreb: Otvoreno sveučilište, 17-46. 
ČERNELIĆ, Milana. 1991. "Proljetni običaji Hrvata”. U Pisanica, ur. Željko Obad. Zagreb: Otvoreno učilište, 23-70.

ČRNELIĆ, Milana. 1993. "Božićni običaji u Hrvata”. U Božićnica. Zagreb: Otvoreno sveučilište, 7-44.

ČERNELIĆ, Milana i Tihana PETROVIĆ. 1998. "From the heritage of the Bunjevci Croats in Bačka". U Iz baštine bačkih Hrvata - Bunjevaca: Etnografski muzej, 17. veljače - 17. ožujka 1998, ur. Milana Černelić, Nevenka Fabian, Tihana Petrović, Marija Šercer, Naco Zelić i Marija Zaić Kubatović. Zagreb: Etnografski muzej, 8-9.

ČERNELIĆ, Milana i Tihana PETROVIĆ. 1998. "Iz baštine bačkih Hrvata Bunjevaca". U Iz baštine bačkih Hrvata - Bunjevaca: Etnografski muzej, 17. veljače - 17. ožujka 1998, ur. Milana Černelić, Nevenka Fabian, Tihana Petrović, Marija Šercer, Naco Zelić i Marija Zaić Kubatović. Zagreb: Etnografski muzej, 5-7.

ČERNELIĆ, Milana. 1998. "O nekim važnijim običajima bačkih Hrvata Bunjevaca". U lz baštine bačkih Hrvata - Bunjevaca: Etnografski muzej, 17. veljače - 17. ožujka 1998, ur. Milana Černelić, Nevenka Fabian, Tihana Petrović, Marija Šercer, Naco Zelić i Marija Zaić Kubatović. Zagreb: Etnografski muzej, 35-39.

ČERNELIĆ, Milana. 1998. "O životu na salašu". U lz baštine bačkih Hrvata Bunjevaca: Etnografski muzej, 17. veljače - 17. ožujka 1998, ur. Milana Černelić, Nevenka Fabian, Tihana Petrović, Marija Šercer, Naco Zelić $i$ Marija Zaić Kubatović. Zagreb: Etnografski muzej, 26-34.

ČERNELIĆ, Milana. 1998. "Sastajanje svatova pred crkvom". U Crkve - Seoske i salašarske crkve u Vojvodini. Novi Sad: Kulturno-istorijsko društvo Pčesa, 742-743

ČERNELIĆ, Milana. 2000. "Prvi rezultati istraživanja tradicijske kulture primorskih Bunjevaca" = "Die ersten Resultaten der Forschung der traditionellen Kultur der kuestenlaendische Bunjewatzer" [Zusammenfassung] = "The first results of the traditional culture research of Bunjevci from the coast" [Summary]. Senjski zbornik: prilozi za geografiju, etnologiju, gospodarstvo, povijest $i$ kulturu, vol. 27:325-328. https://hrcak.srce.hr/29245 (pristup 5. 7. 2019.) 
ČERNELIĆ, Milana. 2013. "Obnovljeni bunjevački običaj ophoda kraljica kao svojevrsni primjer folklorizacije identiteta manjinskih zajednica u Mađarskoj". U Identitet između zbilje i naracije: višestrukost, mijene, prijepori, godišnii skup Hrvatskog etnološkog društvam Zagreb, 6.-7. lipnja 2013. Zagreb: Hrvatsko etnološko društvo, Institut za etnologiju i folkloristiku, Odsjek za etnologiju i kulturnu antropologiju Filozofskog fakulteta Sveučilišta u Zagrebu, 27-28. http://www.hrvatskoetnoloskodrustvo.hr/wp-content/uploads/2013/05/ HED-skup-2013-knjizica-sazetaka.pdf (pristup 5. 7. 2019.)

ČERNELIĆ, Milana. 2013. "Kontituitet i varijacije kraljičkih običaja u podunavskih Bunjevaca" = "Continuity and variations of the pentecost pageant 
(so called kraljice) among the Dunabe area Bunjevci" [Summary]. U 3. FEB: knjiga sažetaka. Međunarodni znanstveni interdisciplinarni simpozij Hrvatska folklorna i etnografska baština u svjetlu dubrovačke, svjetske i turističke sadašnjosti, Dubrovnik 11.-13. prosinca 2013., ur. Mira Muhoberac. Dubrovnik: Folklorni ansambl Linđo, 29-30. http://muzej.lindjo.hr/files/file/FAL\%20D\%201371,\%20Knjiga\%20sa\% C5\%BEetaka\%20za\%20Me\%C4\%91unarodni\%20znanstveni\%20inter diciplinarni\%20simpozij\%203.\%20FEB,\%202013..pdf (pristup 5. 7. 2019.)

ČERNELIĆ, Milana. 2013. "Osvrt na desetljetno sustavno etnološko istraživanje primorsko-ličkih Bunjevaca" = "Review of the ten year systematic ethnological research of the Littoral-Lika Bunjevci" [Summary]. Senjski zbornik: prilozi za geografiju, etnologiju, gospodarstvo, povijest i kulturu, vol. 40:685-696. http://hrcak.srce.hr/129852 (pristup 5. 7. 2019.)

ČERNELIĆ, Milana. 2015. "Ritual traditional clothing among Bunjevci Croats in Serbia". U SIEF 2015: Utopias, Realities, Heritages: Ethnographies for the 21st Century. Zagreb: Department of Ethnology and Cultural Anthropology, Faculty of Humanities and Social Sciences, University of Zagreb, 95. https://nomadit.co.uk/conference/sief2015/paper/25283 (pristup 5. 7. 2019.)

ČERNELIĆ, Milana i Marijeta RAJKOVIĆ IVETA. 2016. "Bunjevačko podgorski identiteti kroz interakcije sa susjednim zajednicama". U Znanstvenostručni skup Podgorje: polazišta i perspektive razvoja kraja između Velebita i Jadrana, Senj, 13.-15. listopada 2016. Gospić: Institut društvenih znanosti Ivo Pilar, Područni centar Gospić - Senj: Gradski muzej Senj - Zagreb: Društvo Senjana i prijatelja Senja "Nehaj", 14. https://www.pilar.hr/wp-content/images/stories/dokumenti/skupovi/ podgorje/Programska_knjizica.pdf (pristup 5. 7. 2019.) 
ČERNELIĆ, Milana. 2017. "Projekt 'Identitet i etnogeneza primorskih Bunjevaca'” / "The 'Identity and Ethnogenesis of the Littoral Bunjevci' Project" [Translation]. Studia ethnologica Croatica, vol. 29:518-526. https://doi.org/10.17234/SEC.29.16 (pristup 5. 7. 2019.)

ČERNELIĆ, Milana. 2017. "Projekt 'Identitet i etnokulturno oblikovanje Bunjevaca'" / "The 'Identity and Ethno-Cultural Formation of the Bunjevci' Project" [Translation]. Studia ethnologica Croatica, vol. 29:526-536. https://doi.org/10.17234/SEC.29.16 (pristup 5. 7. 2019.) in Subotica existing over hundred years: continuity and transformations". U City Rituals: 13th conference of The Ritual Year Working Group, ur. Irina Stahl. Bucharest: International Society for Ethnology and Folklore, 8. https://www.siefhome.org/downloads/wg/ry/RY2018\%20 City\%20Rituals\%20abstracts.pdf (pristup 5. 7. 2019.)

\section{OSTALO}

\section{Sažeci, uvodi, pogovori, prijevodi, bibliografija, feljtoni}

ČERNELIĆ, Milana. 1993. "U devet nastavaka: Uskrsni običaji Hrvata (1):

Post, Pokora". Vjesnik: hrvatski politički dnevnik, 2. travnja, br. 16351:45

ČERNELIĆ, Milana. 1993. "U devet nastavaka: Uskrsni običaji Hrvata (2):

Blagovijest". Vjesnik: hrvatski politički dnevnik, 3. travnja, br. 16352:45.

ČERNELIĆ, Milana. 1993. "U devet nastavaka: Uskrsni običaji Hrvata (3):

Cvjetnica". Vjesnik: hrvatski politički dnevnik, 4. travnja, br. 16353:45. 
ČERNELIĆ, Milana. 1993. "U devet nastavaka: Uskrsni običaji Hrvata (4): Veliki tjedan". Vjesnik: hrvatski politički dnevnik, 5. travnja, br. 16354:35.

ČERNELIĆ, Milana. 1993. "U devet nastavaka: Uskrsni običaji Hrvata (5): Velika subota". Vjesnik: hrvatski politički dnevnik, 6. travnja, br. 16355:29.

ČERNELIĆ, Milana. 1993. "U devet nastavaka: Uskrsni običaji Hrvata (6): Pisanica". Vjesnik: hrvatski politički dnevnik, 7. travnja, br. 16356:29.

ČERNELIĆ, Milana. 1993. "U devet nastavaka: Uskrsni običaji Hrvata (7): Blagoslov jela". Vjesnik: hrvatski politički dnevnik, 8. travnja, br. 16357:29.

ČERNELIĆ, Milana. 1993. "U devet nastavaka: Uskrsni običaji Hrvata (8): Uskrsni krijes". Vjesnik: hrvatski politički dnevnik, 9. travnja, br. 16358:45.

ČERNELIĆ, Milana. 1993. "U devet nastavaka: Uskrsni običaji Hrvata (9): Doba kolanja". Uskrsni Vjesnik: hrvatski politički dnevnik, 10., 11. i 12. travnja, br. 16358:60.

ČERNELIĆ, Milana. 2000. "Predgovor". U GRČEVIĆ, Jure. 2000. Kompolje: narodni život i običaji. Otočac: Katedra Čakavskog sabora pokrajine Gacke, 11-14.

ČERNELIĆ, Milana. 2008. "Uvod: živjeti na Krivom Putu”. U Živjeti na Krivom Putu. Sv. 1: Etnološko-povijesna monografija o primorskim Bunjevcima, ur. Milana Černelić, Marijeta Rajković i Tihana Rubić. Zagreb: Filozofski fakultet Sveučilišta u Zagrebu, Odsjek za etnologiju i kulturnu antropologiju, FF-press - Senj: Gradski muzej, 7-11.

ČERNELIĆ, Milana, Marijeta RAJKOVIĆ i Tihana RUBIĆ. 2009. "Uvod: Živjeti na Krivom Putu. Etnološka monografija o primorskim Bunjevcima, II. svezak". U Živjeti na Krivom Putu. Sv. 2: Etnološka monografija o primorskim Bunjevcima, ur. Milana Černelić, Marijeta Rajković i Tihana Rubić. Zagreb: Filozofski fakultet Sveučilišta u Zagrebu, Odsjek za etnologiju i kulturnu antropologiju, FF-press - Senj: Gradski muzej, 7-12.

ČERNELIĆ, Milana i Sanja LONČAR. 2009. "Uvod: život mladih, pripreme za brak i sklapanje braka". U Živjeti na Krivom Putu. Sv. 3: Život mladih, pripreme za brak i sklapanje braka, ur. Milana Černelić, Marijeta Rajković i Tihana Rubić. Zagreb: Filozofski fakultet Sveučilišta u Zagrebu, Odsjek za etnologiju i kulturnu antropologiju, FF-press - Senj: Gradski muzej, 7-11. 
ČERNELIĆ, Milana. 2014. "Uvodno slovo". U Tradicijska baština i etnokulturni identitet podunavskih Hrvata Bunjevaca, gl. ur. Milana Černelić. Zagreb: Filozofski fakultet Sveučilišta u Zagrebu, Odsjek za etnologiju i kulturnu antropologiju, FF-press - Subotica: Zavod za kulturu vojvođanskih Hrvata, 7-10

UREDNIŠTVO [i. e. Milana ČERNELIĆ, Jadranka GRBIĆ JAKOPOVIĆ, Marijeta RAJKOVIĆ IVETA, Tihana RUBIĆ, Matija DRONJIĆ i Mihovil GOTAL]. 2014. "Proslov". U Bunjevci u vremenskom i prostornom kontekstu, ur. Milana Černelić, Jadranka Grbić Jakopović, Tihana Rubić, Marijeta Rajković Iveta, Matija Dronjić i Mihovil Gotal. Zagreb: Filozofski fakultet Sveučilišta u Zagrebu, Odsjek za etnologiju i kulturnu antropologiju, FF-press - Subotica: Zavod za kulturu vojvođanskih Hrvata, 9-12.

2018 ČERNELIĆ, Milana. 2018. "Etnološka istraživanja Hrvata u Boki kotorskoj". U RAJKOVIĆ IVETA, Marijeta. 2018. Hrvati u Boki kotorskoj: migracije, svadbeni običaji, identiteti. Zagreb: Srednja Europa - Tivat: Kulturno zavičajno udruženje "Napredak" Gornja Lastva, 3-8.

ČERNELIĆ, Milana. 2018. "Uvodna riječ". U Tradicijska baština, identitet i migracije bačkih Hrvata Šokaca, gl. ur. Milana Černelić. Zagreb: Filozofski fakultet Sveučilišta u Zagrebu, Odsjek za etnologiju i kulturnu antropologiju, FF-Press - Subotica: Zavod za kulturu vojvođanskih Hrvata, 7-10.

\section{Recenzije i prikazi}

1994

1998

2001

2002
ČERNELIĆ, Milana. 1994. "Život i smrt jednog časopisa: Etnografija Južnih Slavena u Mađarskoj, 1/1975. do 10/1993". Studia ethnologica Croatica, vol. 6:217-218. https://hrcak.srce.hr/68248 (pristup 5. 7. 2019.)

ČERNELIĆ, Milana. 1998. "Rekli su o knjizi 'Taslak'”. U JAPUNČIĆ, Mile. 1998. Taslak: rječnik sv. Roka. Zagreb: [vlast. nakl.], 334-225.

ČERNELIĆ, Milana. 2001. "Biser u bunjevačkom etnološkom mozaiku". U STANTIĆ, Alojzije. 2001. Kruv naš svagdanji. Subotica: Hrvatski kulturni centar "Bunjevačko kolo", 263-266.

ČERNELIĆ, Milana. 2002. "Recenzija teksta u katalogu Akvareli Sandora Erdödija autorice Slavice Moslavac". U MOSLAVAC, Slavica. 2002. Akvareli Sandora Erdödija. Kutina: Muzej Moslavine, [5]. 
ČERNELIĆ, Milana. 2004. “Recenzija”. U KUJUNDŽIĆ, Stanka. 2004. Naši mladenci: bunjevačke svadbene nošnje na fotografijama od 1870. do 1970. godine: svadbeni običaji Hrvata - Bunjevaca u XX. stoljeću. Subotica: Hrvatsko akademsko društvo, 5.

ČERNELIĆ, Milana. 2012. "Godišnjak za znanstvena istraživanja (br. 1 - br. 3.), ur. Tomislav Žigmanov, Zavod za kulturu vojvođanskih Hrvata, Subotica, 2009.-2011.". Godišnjak za znanstvena istraživanja Zavoda za kulturu vojvođanskih Hrvata, vol. 4:445-448.

ČERNELIĆ, Milana. 2012. "Godišnjak za znanstvena istraživanja (br. 1 - br. 3.), Subotica: Zavod za kulturu vojvođanskih Hrvata". Studia ethnologica Croatica, vol. 24:232-235. http://hrcak.srce.hr/93982 (pristup 5. 7. 2019.)

2017 ČERNELIĆ, Milana. 2017. "Godišnjak za znanstvena istraživanja (br. 4 - br. 8), Subotica: Zavod za kulturu vojvođanskih Hrvata, 2012. - 2016.". Studia ethnologica Croatica, vol. 29:599-605. https://hrcak.srce.hr/191712 (pristup 5. 7. 2019.)

\section{Natuknice u leksikonu}

2006

2007

2010

2017

ČERNELIĆ, Milana. 2006. "Cvitnjak". U Leksikon podunavskih Hrvata - Bunjevaca i Šokaca, sv. 5: C-Ć, gl. ur. Slaven Bačić. Subotica: Hrvatsko akademsko društvo, 20.

ČERNELIĆ, Milana. 2006. "Diver". U Leksikon podunavskih Hrvata - Bunjevaca i Šokaca, sv. 6: D, gl. ur. Slaven Bačić. Subotica: Hrvatsko akademsko društvo, 36-37.

ČERNELIĆ, Milana. 2007. "Enga". U Leksikon podunavskih Hrvata - Bunjevaca i Šokaca, sv. 7: Dž-F, gl. ur. Slaven Bačić. Subotica: Hrvatsko akademsko društvo, 30-31.

ČERNELIĆ, Milana. 2010. "Ivanje, (sveti) Ivan Cvitnjak". U Leksikon podunavskih Hrvata - Bunjevaca i Šokaca, sv. 10: I, gl. ur. Slaven Bačić. Subotica: Hrvatsko akademsko društvo, 86-87.

ČERNELIĆ, Milana. 2017. "Kravalj". U Leksikon podunavskih Hrvata - Bunjevaca i Šokaca, sv. 13: Ko-Kr, gl. ur. Slaven Bačić. Subotica: Hrvatsko akademsko društvo, 113-114. 
ČERNELIĆ, Milana. 2019. "Kum". U Leksikon podunavskih Hrvata - Bunjevaca i Šokaca, sv. 14: Ku-Kv, gl. ur. Slaven Bačić. Subotica: Hrvatsko akademsko društvo, 64-66.

\section{MENTORSTVO}

\section{Doktorske disertacije}

BIRT KATIĆ, Danijela. 2013. Obitelj, imovina, nasljedna pravila i prakse: kontinuitet i promjene u selima bjelovarskoga kraja. Zagreb: D. Birt Katić.

PRĆIĆ, Aleksandra. 2017. Hrvatska manjina u Srbiji i školovanje na hrvatskom jeziku. Zagreb: A. Prćić.

\section{Diplomski radovi}

1991

1998

1999

2000

NJEGOVAN, Jasna. 1991. Svadbeni običaji u Žumberku i Plešivičkom Prigorju. Zagreb: J. Njegovan.

JURKOVIĆ, Jasna. 1998. Sporazumno odvođenje djevojke kao način neredovnog sklapanja braka u selima feričanačke župe. Zagreb: J. Jurković.

PRIMORAC, Jakša. 1999. Običaj predaje djeteta mladenki pri ulasku u novi dom u Hrvata. Zagreb: J. Primorac.

ŠKRBIĆ, Nevena. 1999. Milčetićeva 'Koleda u Južnih Slavena' i običaj biranja kralja. Zagreb: N. Škrbić.

GLAGOLIĆ, Melanija. 2000. Jabuka u svadbenim običajima južnoslavenskih naroda. Zagreb: G. Barbarić.

BARBARIĆ, Gabrijela. 2000. Pitanja oko domaćice zadruge na Livanjskom polju i na susjednim prostorima s osobitim osvrtom na obiteljsku zadrugu Barbarić. Zagreb: M. Glagolić. 
TOMAŠ, Zrinka. 2000. Svadbeni običaji u Štefanju od 40-ih godina do danas. Zagreb: Z. Tomaš.

ANDRIĆ, Marta. 2001. Turcizmi u seoskom govoru Slavonije. Zagreb: B. Vidas.

VIDAS, Barbara. 2001. Običaji u adventu kod moliških Hrvata iz Mudimitra i San Felice-a. Zagreb: B. Vidas.

BULIĆ, Dijana. 2002. Pokladni običaji nekoć i danas u Blatu na Korčuli i okolici. Zagreb: D. Bulić.

ĐURČEVIĆ, Maja. 2002. Dar u božićnim ophodima. Zagreb: M. Đurčević.

KLOPOTAN, Snježana. 2002. Nazivi za dijelove miraza kod južnih Slavena. Zagreb: S. Klopotan.

VARUNEK, Nadia. 2002. Otmica i sporazumno odvođenje nevjeste na području Ravnih kotara: udaja 'na ružno'. Zagreb: N. Varunek.

FRIŠČIĆ, Marija. 2003. Nazivi i tipologija zimskih večernjih sastanaka (na području Hrvatske i Bosne i Hercegovine). Zagreb: M. Friščić.

KREN, Irja. 2003. Svijet i život žene - makedonske Albanke: život u zatvorenosti - stoljetna tradicija u suvremenosti. Zagreb: I. Kren.

MUMLEK, Karmen. 2004. Majsko stablo u odabranim hrvatskim i njemačkim primjerima. Zagreb: K. Mumlek.

BIRT, Danijela. 2005. Transport i transportna sredstva na području Krivog Puta. Zagreb: D. Birt.

KOKOTOVIĆ, Mura. 2008. Maslinarstvo u Ravnim kotarima: mogućnosti primjene rezultata etnoloških istraživanja u razvoju ruralnog turizma. Zagreb: M. Kokotović.

PAVALIĆ, Nikolina. 2008. Nakoljenče. Zagreb: N. Pavalić.

2009 MEŠTROVIĆ, Željka. 2009. Nastajanje novih tradicija: Republika Čečenija u Mariji Bistrici. Zagreb: Ž. Meštrović.

2010 BAĆAC, Valentina. 2010. Tradicijska prehrana ravnokotarskih sela u kontekstu 
ruralnog turizma. Zagreb: V. Baćac.

BERNARDIĆ, Lidija. 2010. Animalistika u etnologiji/antropologiji: prilog promišljanju studijskog kurikuluma. Zagreb: L. Bernardić.

BODROŽIĆ, Maša. 2010. Virdžina: ni muško ni žensko, razmatranja o trećem rodu. Zagreb: M. Bodrožić.

KRZNARIĆ, Ana. 2013. Običaji služenja u ogulinskom kraju. Zagreb: A. Krznarić.

DIMŠIĆ, Katarina. 2015. Običaj prošnje u Bačkom Monoštoru i Bačkom Bregu: mogućnosti muzejske dokumentacije i prezentacije zvučnih zapisa. Zagreb: K. Dimšić.

PERIŠKIĆ, Sonja. 2015. Djetinjstvo, slobodno vrijeme i odrastanje u Bačkom Monoštoru sredinom 20. stoljeća. Zagreb: S. Periškić.

SAJKO, Ivana. 2015. Božićni običaji u Hrvatskoj i Italiji. Zagreb: I. Sajko.

2016 RUŽIĆ, Ivana. 2016. Porodni običaji i položaj žene na području zapadne Bilogore. Zagreb: I. Ružić.

2017 KUŠıć, Tamara. 2017. Bijeli maškari iz Putnikovića na poluotoku Pelješcu. Zagreb: T. Kušić.

NOVOSEL, Martina. 2017. Medvednica - studija slučaja interakcije stanovništva zagrebačkog prigorja i zagorja. Zagreb: M. Novosel. sredine 20. stoljeća. Zagreb: M. Karin. 
PELICARIĆ, Luka. 2018. Narodna vjerovanja bačkih Šokaca Hrvata u Monoštoru i Beregu. Zagreb: L. Pelicarić.

VLAJČEVIĆ, Ana. 2018. Pokladni običaji u Muću. Zagreb: A. Vlajčević.

CRNČIĆ, Anita. 2019. Svadbeni običaji u Dobrinju na otoku Krku.

Zagreb: A. Crnčić.

KAPEŠ, Robert. 2019. Pokladni običaji na području Srijema u Vojvodini. Zagreb: R. Kapeš.

VUKOVIĆ, Sindy. 2019. Posmrtni običaji srijemskih Hrvata u Vojvodini. Zagreb: S. Vuković. 